\title{
O DEVER DE LEALDADE E OS ABUSOS DO DIREITO DE SÓCIO EM SOCIEDADES
}

\section{THE DUTY OF LOYALTY AND ABUSES OF PARTNER RIGHTS IN COMPANIES}

\section{EL DEBER DE LEALTAD Y LOS ABUSOS DEL DERECHO DE SOCIO EN SOCIEDADES}

\begin{abstract}
AlEXANDRE FERREIRA DE ASSUMPÇÃo ALVES
Doutor em Direito pela Universidade do Estado do Rio de Janeiro (UERJ). Professor da Universidade Federal do Rio de Janeiro (UFRJ) e professor do programa de pós-graduação stricto sensu da Faculdade de Direito da UERJ na linha de pesquisa Empresa e Atividades Econômicas. Rio de Janeiro, RJ, Brasil. http://lattes.cnpq.br/4600525837414056 / http://orcid.org/0000-0002-4623-2953 / asaa@uol.com.br
\end{abstract}

ILAN GOLDBERG

Doutorando em direito civil pela Universidade do Estado do Rio de Janeiro (UERJ). Professor dos Cursos de PósGraduação lato sensu em Direito da Universidade Estácio de Sá (Rio de Janeiro). Professor Substituto da Faculdade de Direito da Universidade do Estado do Rio de Janeiro (UERJ). Rio de Janeiro, RJ, Brasil. http: / / lattes.cnpq.br/4199535337003697 / http://orcid.org/0000-0003-1720-9954 / Ilan@cgvf.com.br

\begin{abstract}
RESUMO
O presente artigo tem por finalidade analisar a constituição do contrato de sociedade com ênfase na importância do dever societário de lealdade. Nesse viés, foram realizadas considerações acerca da função social e do interesse da sociedade. Mais especificamente, discorre a respeito dos abusos praticados pelos sócios tanto da perspectiva da minoria, quanto da perspectiva da maioria. Examinam-se determinadas consequências que atingem o próprio mercado como vítima de condutas abusivas. A partir do emprego do método dedutivo e pesquisa bibliográfica, concluiu-se que a disciplina dos abusos por parte de sócios em sociedades deve, necessariamente, remeter à função social do contrato. Por ter o contrato de sociedade função social, quaisquer condutas tomadas pelos administradores devem se pautar no dever de lealdade, estejam eles na condição de representantes dos sócios majoritários ou minoritários. Caso inobservado o dever de lealdade, estará caracterizada a conduta abusiva dos administradores.
\end{abstract}

Palavras-chave: Abuso do direito; dever de lealdade; sociedade.

\begin{abstract}
The present article aims to analyze the conception of the company's contract, emphasizing the importance of the duty of loyalty. In this sense, there are considerations about social function and about corporate interest. Moreover, specifically about the abuses practiced by partners in the perspective of the minority, as well as in the perspective of the majority. The article also looks to consequences that affect the own market as a victim of such abusive conducts. Through the use of the deductive method and literature research, it concluded that the discipline of abuses by partners in companies must necessarily refer to the social function of contracts. For having the contract a social function, any steps taken by the administrators must be based on the duty of loyalty, whether they act as representatives of the majority or minority partners. If the duty of loyalty is unobserved, the abusive conduct of the administrators will be characterized.
\end{abstract}

Keywords: Abuse of rights; duty of loyalty; company. 


\section{RESUMEN}

El presente artículo tiene por objeto analizar la constitución del contrato de sociedad con énfasis en la importancia del deber societario de lealtad. En ese sesgo, se realizaron consideraciones sobre la función social y el interés de la sociedad. Más específicamente, discurre acerca de los abusos practicados por los socios tanto desde la perspectiva de la minoría, como desde la perspectiva de la mayoría. Se examinan determinadas consecuencias que afectan al propio mercado como víctima de conductas abusivas. A partir del empleo del método deductivo e investigación bibliográfica, se concluyó que la disciplina de los abusos por parte de socios en sociedades debe, necesariamente, remitir a la función social del contrato. Por tener el contrato de sociedad función social, cualquier conducta tomada por los administradores debe guiarse en el deber de lealtad, estén ellos en la condición de representantes de los socios mayoritarios o minoritarios. En caso de inobservado el deber de lealtad, se caracterizará la conducta abusiva de los administradores.

Palabras clave: Abuso del derecho; Deber de lealtad; Sociedad.

\section{SUMÁRIO}

INTRODUÇÃO; 10 CONTRATO DE SOCIEDADE, A PESSOA DO SÓCIO E OS INTERESSES ENVOLVIDOS; 1.10 dever societário de lealdade; 1.2 Função e interesse da sociedade; 1.2.1 A função social da sociedade; 1.2.2 0 interesse da sociedade; 2 OS ABUSOS DO DIREITO DE SÓCIO EM SOCIEDADES; 2.1 Condutas abusivas da maioria; 2.2 Condutas abusivas da minoria; 2.3 Direito concorrencial - o mercado como vítima; CONCLUSÃO; REFERÊNCIAS.

\section{INTRODUÇÃO}

A reunião de pessoas em sociedade é prática antiquíssima e pode ser observada em momentos diversos na história da humanidade. Muito antes de se cogitar a respeito da constituição de sociedades formais, o homem sempre teve imbuído em seu espírito a noção de que a consecução de tarefas consideradas difíceis seria menos árdua apenas se concebida coletivamente.

Dentre as várias formas associativas, personificadas ou não, este trabalho centra seu escopo na sociedade personificada, notadamente do tipo anônima. Em que pese a essência do esforço comum para a realização da atividade econômica, frequentemente se verifica a prática de atos abusivos por parte de sócios, controladores ou não. Nestes casos, o dever societário de lealdade está sendo descumprido, com potenciais e reais prejuízos à pessoa jurídica, aos sócios e a terceiros (empregados, fornecedores, credores, sociedade civil, entre outros). Na seara contratual a atuação do sócio fulmina o princípio da função social do contrato e outros que lhe são associados como a boa-fé objetiva, a eticidade e a probidade.

No que tange à pessoa jurídica, com relevo para as grandes corporações, a violação a deveres legais ou estatutários pelos sócios e administradores pode gerar consequências previsíveis e imprevisíveis, que transcendem os limites da atuação da sociedade, envolvendo 
uma rede de colaboradores e, em casos extremos, a economia e o desenvolvimento de uma região ou de um país, dependendo das proporções do dano.

O objetivo central do presente artigo é a investigação sobre a prática de abusos por parte do sócio e suas consequências no âmbito da sociedade e de terceiros. Para tanto, utiliza-se o método dedutivo, partindo da compreensão da regra geral do dever de lealdade inserido na função e interesse da sociedade, para então perscrutar casos específicos relacionados ao abuso do direito de sócio. A pesquisa realizada é do tipo bibliográfica.

0 trabalho foi estruturado em duas partes. Na primeira, será exposto o contrato de sociedade com ênfase na pessoa do sócio e dos interesses que gravitam em torno da pessoa jurídica, como dos fornecedores e empregados, por exemplo. Também nessa parte do trabalho serão analisados o dever societário de lealdade, a função e o interesse da sociedade e os abusos dos sócios em sociedades. Na segunda e última parte, âmago do artigo, enfrenta-se a questão dos abusos do direito de sócio, apresentando casos relacionados ao poder de controle, abuso por parte da maioria e minoria acionária e reflexos do abuso no direito concorrencial.

\section{CONTRATO DE SOCIEDADE, A PESSOA DO SÓCIO E OS INTERESSES ENVOLVIDOS}

Absolutamente diversas podem ser as motivações que conduzem pessoas à constituição de sociedades ou, conforme expresso no Código Civil brasileiro em seu art. 981, à celebração de contratos de sociedade, com a condição óbvia de que o objeto perseguido seja lícito (art. 104, CC). Da definição prevista no art. 981, lê-se “celebram contrato de sociedade as pessoas que reciprocamente se obrigam a contribuir, com bens ou serviços, para o exercício de atividade econômica e a partilha, entre si, dos resultados"1.

Dependendo da complexidade da atividade econômica a ser realizada e seus custos, a pessoa que pretenda empreender terá dificuldades para alcançar seu desiderato sozinha ${ }^{2}$. Com isso, uma solução possível para perseguir na pretensão é a busca de parceiros que queiram

\footnotetext{
${ }^{1}$ BRASIL. Lei $n^{\circ}$ 10.406, de 10 de janeiro de 2002. Código Civil. Diário Oficial da República Federativa do Brasil, Brasília, DF, 11 jan. 2002.2 Disponível em: http://www.planalto.gov.br/ccivil_03/leis/2002/L10406.htm. Acesso em: 18 jul. 2017.

${ }^{2}$ Fica ressalvada a possibilidade de constituição de Empresa Individual de Responsabilidade Limitada (EIRELI) nos termos do art. 980-A do Código Civil, que se caracteriza pela unipessoalidade permanente.
} 
constituir sociedade, com o propósito de arregimentar maiores recursos financeiros, melhorar a organização, obter benefícios tributários, entre outros ${ }^{3}$.

Da redação do disposto no art. 981, verifica-se menção a pessoas que, reciprocamente, se obrigam a contribuir, tendo como finalidade determinada atividade econômica e a posterior partilha dos resultados, qual seja, lucros e perdas. A reflexão a respeito da reciprocidade a que o Código se refere conduz a uma comunhão de interesses comuns e, no seio das sociedades cum intuitu personae, via de regra de menor porte em relação às grandes sociedades, uma boa dose de afinidade entre os sócios é altamente recomendável. Difícil imaginar o início de uma pequena sociedade na qual seus dois sócios hipotéticos se detestem ${ }^{4}$.

Passando-se a observar as chamadas sociedades de capital, as características pessoais de cada acionista cedem espaço para o capital empregado na atividade social. Assim, enquanto que nas sociedades de pessoas privilegiam-se aspectos como competência, dedicação e eficiência dos sócios, nas de capital concentra-se o foco justamente no investimento realizado, geralmente disperso numa grande quantidade de acionistas ${ }^{5}$. Sob a perspectiva da comunhão de

${ }^{3}$ Não é demasiado lembrar que determinadas atividades econômicas, por sua relevância e interesse público envolvidos no exercício da empresa, exigem sejam observadas certas formas típicas de sociedades como, por exemplo, as sociedades anônimas para bancos múltiplos (Resolução CMN n² 2.099, de 1994) e também para operações de seguros privados (Decreto-Lei n 73/66, art. 24).

${ }^{4}$ O Superior Tribunal de Justiça apreciou hipótese na qual numa sociedade de pessoas, determinado sócio pretendia valer-se de provimento jurisdicional para, forçosamente, ingressar no quadro de sócios. A Corte, mencionando a necessidade da affectio societatis, reputou incabível a pretensão do sócio demandante: "Recurso especial. Ação de rescisão de contrato cumulada com perdas e danos. Extensão da obrigação. Interpretação de cláusulas contratuais. Reexame de provas. Súmulas 5 e 7/STJ. Affectio societatis. Ruptura. Inexequibilidade do contrato social. Obrigação de fazer. Ingresso em sociedade limitada. Determinação judicial. Não cabimento. [...] 3. Em contrato preliminar destinado a ingresso em quadro de sociedade limitada, a discussão passa pela affectio societatis, que constitui elemento subjetivo característico e impulsionador da sociedade, relacionado à convergência de interesses de seus sócios para alcançar o objeto definido no contrato social. A ausência desse requisito pode tornar inexequível o fim social. Inteligência dos arts. 1.399, inciso III, do Código Civil de 1916 ou 1.034, inciso II, do Código Civil de 2002, conforme o caso. 4. Apresenta-se incabível provimento jurisdicional específico que determine 0 ingresso compulsório de sócio quando ausente a affectio societatis, motivo pelo qual se impõe a reforma do acórdão recorrido para decretar a resolução do contrato, a fim de que se resolva a questão em perdas e danos. [...]." (BRASIL. Superior Tribunal de Justiça. Recurso Especial $n^{\circ}$ 1192726/SC. Francisco Francovig e outros; Santa Terezinha Transportes e Turismo Ltda. Relator: Min. Ricardo Villas Bôas Cueva. 20 de março de $2015 . \quad$ Disponível https://ww2.stj.jus.br/processo/revista/documento/mediado/?componente=ITA\&sequencial=1390551\&nu m_registro $=201000836598 \mathrm{~d} d a t a=20150320 \&$ formato=PDF. Acesso em: 19 jul. 2017.)

${ }^{5} 0$ Superior Tribunal de Justiça fez exatamente esta distinção entre sociedades de pessoas versus sociedades de capital. Cita-se o trecho da ementa do acórdão mais relevante para a exposição "[...] 6. A pretensão deduzida no recurso negligencia uma diferença marcante entre as sociedades anônimas (geralmente de capital) e as sociedades limitadas (geralmente de pessoas, nas quais predomina a affectio societatis): nas sociedades anônimas, a lei dificulta o reembolso das ações ao acionista dissidente, incentivando a alienação das ações para que terceiros ingressem em seus quadros; em contraste, nas 
ISSN 1981-3694

(DOI): $10.5902 / 1981369424912$

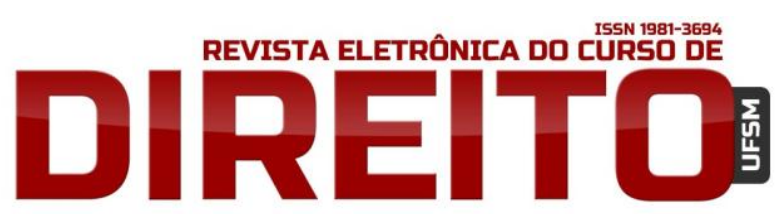

O DEVER DE LEALDADE E OS ABUSOS DO DIREITO DE SÓCIO EM

SOCIEDADES

AleXANDre Ferreira de AsSUmpÇão AlVES ILAN GOLDBERG

interesses derivada da reciprocidade, a sociedade de pessoas permite um olhar mais claro, haja vista que seus sócios, no cotidiano, muito provavelmente estarão até mesmo trabalhando juntos, de maneira que eventuais condutas contrárias aos interesses comuns serão facilmente perceptíveis e, conforme forem, ajustáveis.

A questão torna-se mais instigante ao examinar a multiplicidade de interesses que habitam todos e cada um dos acionistas de uma grande sociedade de capital. Nesse sentido, basta pensar que, em não raras ocasiões, estarão convivendo as mais diversas espécies de sócios, quais sejam, aqueles que têm poder de voto (titulares das ações ordinárias), os que não o têm (ações preferenciais), acionistas que, concomitantemente, ostentem a figura de controladores da companhia, na qualidade de administradores/diretores, meros investidores que, simplesmente, aplicam seus recursos no mercado de bolsa de valores com o único propósito de auferir dividendos pagos pela companhia, entre outros.

Embora num plano diferente dos acionistas propriamente ditos, convém ressaltar que também estarão convivendo com a companhia e seus acionistas os empregados, credores, associações de classe e, a depender do tipo de atividade empresarial desempenhada, as mais diversas instituições públicas e privadas, como agências reguladoras, Ministério Público, órgãos de proteção ao meio ambiente e aos consumidores. Exsurge, portanto, a necessidade de que seja buscado um equilíbrio bastante sensível entre todos esses personagens.

A reciprocidade interpessoal, característica do contrato plurilateral, traz em si valores como afinidade, senso de comunhão e harmonia, o que remete à affectio societatis ${ }^{6}$. Esse liame entre sócios relaciona-se ao dever de lealdade deles em relação à sociedade. Tal dever, previsto

sociedades limitadas, a lógica é inversa, pois a lei tem predileção pela dissolução parcial - com apuração dos haveres - e dificulta o ingresso de terceiros nos quadros societários, haja vista que sua essência reside exatamente no vínculo pessoal entre os consorciados." (BRASIL. Superior Tribunal de Justiça. Recurso Especial 1179342/GO. Cilene Maria Elias Metran e Goiás Refrigerantes S/A. Relator: Min. Luis Felipe Salomão. 01 de agosto de $2014 . \quad$ Disponível em: https://ww2.stj.jus.br/processo/revista/documento/mediado/?componente=ITA\&sequencial=1325480\&nu m_registro=201000260074\&data $=20140801 \&$ formato=PDF. Acesso em: 19 jul. 2017.)

${ }^{6}$ Destacando a importância dessas características nas sociedades de pessoas, Marcelo Marco Bertoldi e Marcia Carla Pereira Ribeiro afirmam: “[...] No entanto, foi na pujança mercantilista da Idade Média, especialmente nas cidades italianas, que surgiu o modelo mais próximo do que hoje se entende por sociedade empresária, desenvolvendo-se a ideia de separação dos patrimônios dos sócios em relação ao patrimônio da sociedade. Nessa época, as sociedades eram eminentemente intuitu personae, ou seja, o que aproximava os sócios eram suas características pessoais e seus objetivos em comum. É o que se denomina de affectio societatis, característica existente até os dias de hoje nas chamadas sociedades de pessoas." (BERTOLDI, Marcelo M; RIBEIRO, Marcia Carla P. Curso avançado de direito comercial. 5. ed. São Paulo: RT, 2009. p. 145) 


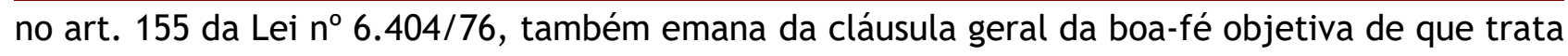
o art. 422 do Código Civil.

\subsection{0 dever societário de lealdade}

Marcelo Vieira von Adamek refere-se à tríplice função do dever de lealdade nas sociedades: atuar como cânone hermenêutico e integrativo, como limite ao exercício de posições jurídicas subjetivas e como fonte de deveres anexos de conduta:

O dever de lealdade aplica-se a todos os sujeitos da relação societária, na sua interação com a sociedade e com os sócios entre si. O controlador, pelo poder que tem de definir os rumos da sociedade, de decidir vinculantemente também para a minoria e, com isso, indiretamente dispor de patrimônio alheio, responde por deveres mais intensos de lealdade. No entanto, também a minoria pode, no exercício das suas posições jurídicas subjetivas, influir na esfera alheia, sobretudo quando dispõe do poder de bloquear determinadas deliberações societárias, e, por isso, também responde por deveres de lealdade. Em cada caso, porém a intensidade desses deveres depende da concreta situação jurídica do sócio e, para isso, têm influência a participação detida, os poderes de que é titular (se tem ou não certos direitos de minoria, de administração ou direitos especiais) e a estrutura real da sociedade - embora, em qualquer caso, até mesmo em autênticas sociedades de capitais haja deveres de lealdade entre os sócios. Tais deveres impregnam, outrossim, toda a relação societária e perduram não só durante o ciclo normal de execução do contrato, mas antes e depois dele, nas fases pré e pós contratual.

Tal qual a boa-fé objetiva, da qual se despregou, o dever societário de lealdade é uma cláusula geral e, portanto, carece de mediação concretizadora; além disso, exerce a tríplice função de atuar como cânone hermenêutico e integrativo, limite ao exercício de posições jurídicas subjetivas e fontes de deveres anexos de conduta. ${ }^{7}$

Observando a temática proposta acima pelo autor, o dever de lealdade - calcado na boa-fé objetiva - opera como uma espécie de eixo principal, do qual devem derivar todas as condutas realizadas pelos sócios. Não se espera dos mesmos "sentimentos puros da alma" amor, compaixão ou caridade; não obstante, de modo pragmático, o dever de lealdade se traduz numa conduta que, se descumprida, pode ensejar diversos abusos tanto por parte da minoria quanto por parte da maioria.

O dever de lealdade desdobra-se em comportamentos positivos e negativos que efetivamente põem-se em relevo. Não basta, por exemplo, exercer o direito de voto em conformidade com o interesse social (comportamento positivo); cumpre, também, deixar de se

\footnotetext{
${ }^{7}$ ADAMEK, Marcelo Vieira von. Abuso de minoria em direito societário. São Paulo: Malheiros, 2014. p. 6364.
} 
abster de votar quando colocado em xeque o interesse social, o que a doutrina chama de absenteísmo $^{8}$. Que se tenha o dever societário de lealdade em mente de maneira permanente, funcionando como um verdadeiro norte a ser observado por todos os sócios no seio da vida social, independentemente da classe ou espécie de suas ações ou quotas.

$\mathrm{Na}$ medida em que os estudos de direito societário se aprofundam, mais e mais o dever de lealdade se faz presente, trespassando desde as questões mais triviais até as mais complexas. Seja no ato de constituir uma sociedade, propor aumento do capital social, abrir o capital em bolsa, prestar informações ao mercado, nas tomadas de controle, exercício do direito de voto (viés positivo) ou abster-se de votar (viés negativo), entre tantas outras possibilidades, o dever estará presente, espraiando-se valorosamente em diversos institutos do direito societário.

Arnoldo Wald, discorrendo a respeito da governança corporativa, tece considerações interessantes quanto ao chamado fim do "absolutismo na sociedade anônima", exatamente porque a companhia deixa de ser propriedade de seus controladores ou da maioria. Segundo o autor, o dever de lealdade deve ser a tônica, a verdadeira guia para o comportamento salutar de todos os acionistas, não importando a quantidade, espécie e classe de ações que titularizem:

[...] De qualquer modo, a instauração do Estado de Direito e o fim do absolutismo na sociedade anônima significam que ela deixou de ser propriedade individual e exclusiva do acionista controlador, para dar origem a uma parceria,

\footnotetext{
8 “[...] A dispersão acionária pelo grande público, que é característica das sociedades anônimas abertas, originou, contudo, o absenteísmo acionário, que é o marcante desinteresse da maior parte dos proprietários de ações em participar das assembleias gerais e tentar influir na gestão da companhia. 0 absenteísmo torna inoperantes os direitos assegurados às minorias qualificadas, na medida em que estas não conseguem alcançar o quórum mínimo exigido pela lei. 0 absenteísmo tem como uma das causas o fato de a aquisição de ações se dar por diferentes motivos. Essa constatação levou a que se classificassem os acionistas quanto aos interesses que os impulsionavam à aquisição de ações, dividindo-os em: empresários, especuladores e rendeiros. É forçoso afirmar, ainda, que, quanto maior a dispersão, maior o número de pessoas que buscam, no mercado de ações, apenas uma fonte de rendimentos, seja na forma de dividendos, seja mediante as valorizações dos títulos (rendeiros e especuladores, respectivamente). 0 absenteísmo influenciou, sob dois aspectos distintos, o estudo das minorias societárias. Em primeiro lugar, constatou-se que o controle, em razão desse elevado desinteresse, poderia ser mantido com uma ínfima participação no capital da sociedade. Assim, passou-se a tratar a questão das minorias, e de sua tutela, em função da oposição entre a maioria de acionistas não organizados e a minoria que os controla. 0 absenteísmo pôs à lume, ainda, não só a oposição de interesses entre a massa de acionistas e o controle, mas também entre os próprios grupos de acionistas minoritários. 0 estudo das minorias, assim, pode se referir aos grupos de acionistas (acionistas-empresários) atuantes e interessados na administração da companhia, mas que se encontram alijados do poder em razão de não pertencer ao controle; ou aos grupos de acionistas formados por pequenos investidores (acionistas especuladores e rendeiros), detentores, muitas vezes, da maior parte do capital social, mas que, por desinteresse e inaptidão, encontram-se distantes da gestão social. [...]". (AGUIAR, Danilo Augusto Barboza de. Proteção dos acionistas minoritários nas sociedades anônimas abertas como forma de promover o desenvolvimento do mercado de capitais nacional. Alterações no regime legal das ações preferenciais. In: Revista de Direito Bancário e do Mercado de Capitais, v. 22, out./dez. 2003. p. 95).
} 
ISSN 1981-3694

(DOI): $10.5902 / 1981369424912$

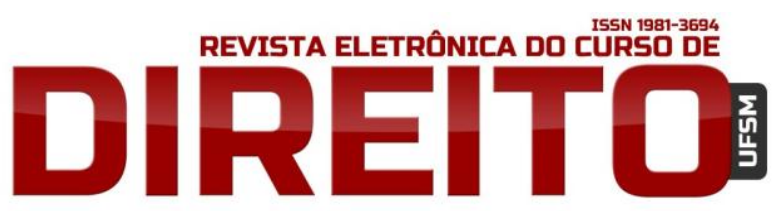

O DEVER DE LEALDADE E OS ABUSOS DO DIREITO DE SÓCIO EM

SOCIEDADES

AleXANDre Ferreira de AsSUmpÇão AlVes ILAN GOLDBERG

exigindo, pois, um novo padrão de conduta por parte dos administradores e dos maiores acionistas. É preciso que todos atuem sempre com boa-fé e lealdade. A boa-fé deve ser objetiva e não subjetiva, não bastando que a pessoa acredite que a sua conduta é a mais adequada.

É necessário que a atuação esteja de acordo com os padrões dominantes na sociedade em determinado momento histórico. A lealdade, por sua vez, não é tão-somente a ausência de deslealdade, tal como o amor não é tão-somente a ausência de ódio. Lealdade é uma atitude de diligência no cumprimento das obrigações contratuais e uma verdadeira affectio contractus.

No fundo, a boa-fé, a lealdade e a probidade, que se exigem do administrador e do controlador da empresa, correspondem à definição de Treu und Glauben, do art. 242 do CC alemão, no qual se determina a sinceridade (veracidade) e a boafé dos contratantes tanto no firmamento quanto na execução do contrato. Constituem, na lição de Ripert, a introdução da regra moral no direito, com o propósito de atenuar, reforçar ou afinar a norma jurídica para compatibilizá-la com a ética. $[. . .]^{9}$

Pelos ensinamentos do autor é possível perceber que lealdade, sinceridade (veracidade) e boa-fé, antes, durante e depois de eventualmente dissolvida a sociedade, é o conjunto de valores que preenchem o padrão de conduta que a vida em sociedade reclama no direito societário brasileiro. 0 dever de lealdade decorre do dever de diligência (art. 153 da Lei $n^{\circ}$ 6.404/76 e art.1.011 do Código Civil) e, ao atuar como administrador da sociedade, o sócio deve se pautar pelas regras éticas do negócio, abstendo-se de praticar atos ou tomar decisões que não faria caso estivesse gerindo seus próprios negócios e interesses.

Se o sócio administrador for responsabilizado civilmente por ato ilícito praticado em detrimento da companhia, mas ficar comprovado que não se afastou do dever de lealdade, o juiz poderá reconhecer a exclusão da responsabilidade, se convencido de que ele agiu de boa-fé e visando ao interesse da companhia (art. 159, § $6^{\circ}$, Lei $n^{\circ}$ 6.404/76). Tal disposição legal é fruto da Common Law, estando embasada na "regra de julgamento do negócio" (business judgment rule $)^{10}$. Trata-se de uma forma de proteção para o administrador da companhia admitida pelos Tribunais dos países de tradição anglo-saxã.

0 cotidiano de uma grande sociedade de capitais é marcado pela necessidade constante de tomada de decisões sérias, impactantes do ponto de vista financeiro e social, de maneira que se exige de seus administradores agilidade, informação adequada para decidir, respeito aos

\footnotetext{
${ }^{9}$ WALD, Arnoldo. 0 governo das empresas. Revista de Direito Bancário e do Mercado de Capitais, v. 5 , n. 15, jan./mar. 2002. p. 53.

10 "[...] a regra do business judgment rule busca evitar que pessoas capazes fiquem com receio de administrar uma companhia, sabendo que poderão colocar em risco ou até perder todo seu patrimônio pessoal quando assumirem qualquer risco, mesmo que inerente à atividade da companhia. A regra tem por finalidade estabelecer parâmetros para evitar a responsabilização do administrador que agiu de boa-fé e nos interesses da companhia." (SILVA, Alexandre Couto. Responsabilidade Civil dos Administradores de S/A: business judgment rule. Rio de Janeiro: Elsevier, 2007. p. 142)
} 
contratos e, por que não dizer, certa dose de ousadia em determinadas situações. Considerando o preenchimento desses requisitos, a business judgment rule protege o bom gestor da empresa, evitando que se possa cogitar de sua responsabilidade pessoal caso alguma decisão venha a causar prejuízos ${ }^{11}$.

A boa-fé objetiva e o dever societário de lealdade afiguram-se importantíssimos e, direta ou indiretamente, estarão presentes na ratio de todos os exemplos práticos de abusos, seja por parte da maioria ou minoria que titulariza as frações do capital com direito a voto.

\subsection{Função e interesse da sociedade}

A positivação das cláusulas gerais de boa-fé objetiva (art. 422) e da função social do contrato (art. 421) representou uma real mudança de perspectiva no ordenamento jurídico brasileiro, comparativamente àquela que caracterizou o Código Civil de 1916. O atual Código Civil, definitivamente, refletiu uma mudança na forma de experimentar e viver o direito. Foi mitigada a autonomia privada da vontade exacerbada e de forte influência do Código Civil francês, do pacta sunt servanda elevado à sua mais alta potência, valendo a máxima segundo a qual "o contrato fazia lei entre as partes" e que ao juiz, na qualidade de "boca da lei", caberia apenas buscar no Código a solução para todos os problemas existentes.

Atentando especificamente à função social do contrato, o entendimento pretérito, que o enxergava como um instituto pronto e acabado em si mesmo e de aplicação restrita às partes, cedeu espaço para uma proposta mais abrangente, preenchida pela valoração principiológica da Constituição Federal, tanto os princípios fundantes da República (art. $3^{\circ}$ ) quanto os relacionados à Ordem Econômica (art. 170). Esta transformação também atingiu o contrato de sociedade, como se examinará no item 1.2.1.

Na Exposição de Motivos do anteprojeto de Código Civil, Miguel Reale realça que um dos aspectos fundamentais do Livro consagrado ao Direito das Obrigações é “Tornar explícito, como princípio condicionador de todo o processo hermenêutico, que a liberdade de contratar só pode ser exercida em consonância com os fins sociais do contrato,

\footnotetext{
${ }^{11}$ Cf. WARDE JÚNIOR, Walfrido Jorge; CASTRO, Rodrigo Rocha Monteiro de. Poderes de controle no âmbito da companhia. In: CASTRO, Rodrigo Rocha Monteiro (Coord.). Direito Empresarial e outros estudos em homenagem ao Professor José Alexandre Tavares Guerreiro. São Paulo: Quartier Latin, 2013. p. 510.
} 
ISSN 1981-3694

(DOI): $10.5902 / 1981369424912$

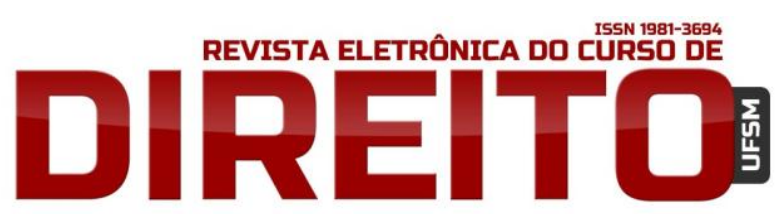

O DEVER DE LEALDADE E OS ABUSOS DO DIREITO DE SÓCIO EM

SOCIEDADES

ALEXANDRE FerReira de ASSUMPÇ̃̃o ALVES ILAN GOLDBERG

implicando os valores primordiais da boa-fé e da probidade"12, bem como da eticidade, socialidade e solidariedade. Tais valores foram consagrados nos arts. 421 e 422 do Código Civil.

A conjugação do art. 421 com o art. 2.035 do Código Civil revela que todo contrato, inclusive o de sociedade, na qualidade de negócio jurídico inserido dentro de um sistema, jamais poderia contrariar a sua função social e a ordem pública. O contrato não mais se encerraria em si mesmo, de maneira por assim dizer egoísta, passando a carregar uma densidade axiológica maior e mais profunda, o que também teve repercussão sobre a função social da sociedade. 0 comentário de Emílio Betti é preciso nessa direção: “O direito [...] não dá o seu apoio ao capricho e ao arbítrio individual, mas a funções práticas que tenham uma relevância e uma utilidade social, e que, por isso mesmo, mereçam ser estavelmente organizadas” ${ }^{13}$.

Enzo Roppo, ao estudar o contrato e a propriedade, comenta a respeito de uma característica estática da propriedade, ao passo que o contrato, em sentido oposto, seria dinâmico. Ao distinguir os dois institutos, o autor inicia afirmando que nas sociedades do capitalismo nascente a propriedade era enxergada quase como um dogma,

[...] a verdadeira e única fonte de produção e fruição das utilidades económicas, enquanto ao contrato se assinalava o papel - complementar - de simples meio para a sua circulação, para a transferência daquele senhorio de um sujeito para outro: a única e verdadeira riqueza económica era representada pela propriedade; o contrato não criava riqueza, antes se limitava a transferi-la ${ }^{14}$.

Em abono a essa doutrina percebe-se que com a chegada da industrialização, das novas tecnologias e do desenvolvimento, houve uma notável mudança nessa relação 'protagonista versus coadjuvante', na exata medida em que o contrato, de mero agente responsável pela transferência da propriedade, passou a ser o real responsável por sua criação. Enzo Roppo comenta a importância do contrato vis-à-vis a propriedade:

Mas já nesta perspectiva deveria reconhecer-se que, permanecendo embora firmes a posição e o papel proeminentes da propriedade no sistema económico (para o que ocorreu uma profunda revisão do conceito de propriedade), a relação entre propriedade e contrato resulta, em qualquer caso, transformada em profundidade: porque agora o contrato não se limitaria a transferir a propriedade, mas até mesmo a criaria. Mas em rigor não parece necessário nem

\footnotetext{
12 REALE, Miguel. Novo código civil: exposição de motivos e texto sancionado. 2. ed. Brasília: Senado Federal, Subsecretaria de Edições Técnicas, 2005. Disponível em: http://www2.senado.leg.br/bdsf/item/id/70319. Acesso em: 12 ago. 2016.

${ }_{13}$ BETTI, Emilio. Teoria geral do negócio jurídico. Tomo I. Tradução de Ricardo Rodrigues Gama. Campinas: LZN, 2003. p. 150.

${ }^{14}$ ROPPO, Enzo. O contrato. Tradução de Ana Coimbra e M. Januário C. Gomes. Coimbra: Almedina, 2009. p. 63-64.
} 
oportuno recorrer a um tal artifício lógico: parece mais razoável considerar que, em todos esses casos, existe riqueza ("imaterial”, mas nem por isso menos relevante) que não se concretiza na forma tradicional do direito de propriedade, e que tal riqueza é produzia directamente pelo contrato. Neste sentido, dentro de um sistema capitalista avançado parece ser o contrato, e já não e propriedade, o instrumento fundamental de gestão dos recursos e de propulsão da economia. ${ }^{15}$

Com base neste tecido teórico, na qualidade de instituto responsável pela criação de riquezas e sob inspiração da densa carga de princípios constitucionais como a função social da livre iniciativa e a função social da propriedade, o contrato, no Código de 2002, passou a exercer uma função distinta e com reflexos diretos na função social da sociedade.

\subsubsection{A função social da sociedade}

Antes de repercutir nas ciências sociais, o estudo da função social, inicialmente, concentrou-se no exame da propriedade, destacando-se os posicionamentos de Karl Renner e Léon Duguit. Sinteticamente, Karl Renner ${ }^{16}$ observava na função social o retrato da função econômica do mesmo instituto. Segundo esse posicionamento, até mesmo uma propriedade improdutiva atenderia a uma função social, já que a função econômica existe tanto em propriedades produtivas quanto nas improdutivas. No polo oposto, Léon Duguit ${ }^{17}$ preconizava o abandono da característica meramente individualista ligada à vontade humana, propondo que a função social tivesse um escopo promocional, sucedendo-se o embate entre as duas posições.

Guilherme Calmon Nogueira da Gama, apoiado em Fábio Konder Comparato, chama a atenção para uma característica própria da função social nos tempos hodiernos, que lhe outorga um direito subjetivo e um dever jurídico:

Se analisarmos mais de perto esse conceito abstrato de função, em suas múltiplas espécies, veremos que o escopo perseguido pelo agente é sempre o interesse alheio, e não o próprio do titular do poder. O desenvolvimento da atividade é, portanto, um dever, mais exatamente, um poder-dever; e isto, não no sentido negativo, de respeito a certos limites estabelecidos em lei para o exercício da atividade, mas na acepção positiva, de algo que deve ser feito ou cumprido ${ }^{18}$.

\footnotetext{
${ }^{15}$ ROPPO, Enzo. O contrato. Tradução de Ana Coimbra e M. Januário C. Gomes. Coimbra: Almedina, 2009. p. 66.

${ }_{16}$ RENNER, Karl. The Institutions of Private Law and their Social Functions. New Brunswick (U.S.): Transaction Publishers, 2010. p. 195.

17 DUGUIT, Léon. Las transformaciones del Derecho Publico y Privado. Buenos Aires: Heliasta S.R.L., 1975. p. 290.

${ }^{18}$ GAMA, Guilherme Calmon Nogueira da; BARTHOLO, Bruno Paiva. Função social da empresa. In: Revista dos Tribunais, v. 96, n. 857, mar. 2007, p. 11.
} 
ISSN 1981-3694

(DOI): $10.5902 / 1981369424912$

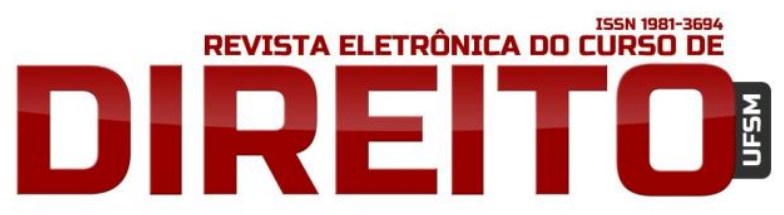

O DEVER DE LEALDADE E OS ABUSOS DO DIREITO DE SÓCIO EM

SOCIEDADES

ALEXANDRE FERREIRA de ASSUMPÇÃo ALVES ILAN GOLDBERG

O “poder-dever” enunciado por Fábio Konder Comparato vai justamente ao encontro da forma por meio da qual a função social da sociedade deve operar no ordenamento jurídico brasileiro. A Constituição da República, em seu art. 170, como eixo centralizador de todo o sistema, traz em si os chamados princípios de integração, traduzidos na defesa do consumidor, do meio ambiente, busca de pleno emprego e redução de desigualdades sociais ${ }^{19}$.

Nesse sentido, a sociedade, além de buscar o lucro a ser distribuído entre os seus acionistas, deverá concomitantemente ocupar-se dos referidos princípios, deixando de lado o posicionamento pretérito que encerrava na órbita societária endógena um fim em si mesmo ${ }^{20}$. Exatamente nesse sentido é o comentário de Arnoldo Wald que, cotejando passado e presente, afirma:

Do ponto de vista técnico, podemos dizer que o conjunto de medidas que assegura o funcionamento eficiente, rentável e equitativo das empresas deve assegurar a prevalência do interesse social sobre os eventuais interesses particulares dos acionistas, sejam eles controladores, representantes da maioria ou da minoria. Trata-se, portanto, da criação do Estado de Direito dentro da sociedade anônima, em oposição ao regime anterior de onipotência e de poder absoluto e discricionário do controlador ou grupo de controle. Cria-se, dessa forma, um sistema de equilíbrio e separação dos poderes para substituir a vontade do príncipe que tinha, no passado, força de lei. ${ }^{21}$

Cumpre distinguir a função da responsabilidade social da sociedade. No século XXI, diante da flagrante ineficiência do Estado, o empresariado privado acabou avocando para si mais e mais atribuições que, ao menos legalmente, não the seriam imputáveis. Ao caminhar pelas ruas, avenidas e parques de grandes metrópoles mundo afora, quantos exemplos de altruísmo

${ }^{19}$ COMPARATO, Fábio Konder. Estado, empresa e função social. Revista dos Tribunais, São Paulo, v. 85, n. 732, out. 1996. p. 41.

20 Nesse sentido, cabe mencionar o Enunciado 2.14, proposto na II Jornada de Direito Comercial: "Proposição 2.14. Resumo das proposições: a) a função social da empresa e os princípios previstos no artigo 170 da Constituição Federal devem nortear a determinação do interesse da companhia. Portanto, o interesse da companhia deve incluir, razoável e proporcionalmente, o interesse de todos os acionistas, dos empregados, dos credores, dos consumidores e da sociedade, bem como a defesa do meio ambiente. b) Do princípio da função social da empresa decorre um complexo de deveres e obrigações, positivas e negativas, impostas aos controladores e administradores, perante os sócios minoritários, empregados, fornecedores, consumidores, meio-ambiente, Estado, e toda a comunidade que com ela interage, cujos interesses devem ser compatibilizados com a busca do lucro. c) Na interpretação das normas relativas às empresas [sic] que desenvolvam atividades consideradas socialmente relevantes, deve-se levar em consideração a sua função social e a sua natureza institucional, da qual decorrem deveres e responsabilidades para com a comunidade em que vivem."

${ }^{21}$ WALD, Arnoldo. 0 governo das empresas. Revista de Direito Bancário e do Mercado de Capitais, v. 5 , n. 15, jan./mar. 2002. p. 2. 
empresarial não podem ser identificados? Canteiros, avenidas, mobiliários urbanos, parques, etc., são "adotados" pela iniciativa privada, gerando benefícios para toda a comunidade.

Investimentos com recursos privados são cada vez mais realizados em searas que, até bem pouco tempo atrás, eram realizados exclusivamente pelo Estado. Segurança pública, saneamento, educação, esporte e cultura, apenas para exemplificar alguns, foram objeto de iniciativas empreendidas por particulares, o que se convencionou chamar de responsabilidade social das sociedades ou, também, de "empresa-cidadã".

Percebe-se que o principal traço distintivo entre a função social da sociedade e sua responsabilidade social consiste na sua qualificação: a responsabilidade social é mera faculdade da pessoa jurídica tomar medidas de cunho assistencial e promocional; por outro lado, a função social da sociedade decorre de valorosa carga axiológica que emana da Constituição Federal, notadamente o valor social da livre iniciativa (art. $1^{\circ}$, IV). Portanto, cumprirá aos sócios controladores o "poder-dever" de observá-la, dirigindo o cotidiano dos seus negócios, valorando a defesa do meio ambiente, dos consumidores, reduzindo as desigualdades sociais e buscando o pleno emprego, etc. As sociedades do século XXI devem procurar, além de distribuir dividendos aos seus acionistas, zelar e, com razoabilidade e proporcionalidade, promover o desenvolvimento na comunidade em que estiverem inseridas.

\subsubsection{0 interesse da sociedade}

De maneira sutilmente diferente daquela empregada no art. 981 do CC, a Lei $n^{\circ}$ 6.404/76 (Lei das S.A.) alude, frequentemente, à noção de interesse. Considerando os múltiplos personagens acima referidos, qual seria o interesse tutelado pela lei acionária? Qual seria o interesse perseguido por uma sociedade anônima?

Erasmo Valladão Azevedo e Novaes França, em sua tese de doutorado cuja temática está voltada aos conflitos de interesses nas assembleias gerais de S.A., discorre a respeito do que caracteriza o interesse. Em primeiro lugar, o autor explica:

Por interesse pode-se entender a relação existente entre um sujeito, que possui uma necessidade, e o bem apto a satisfazê-la, determinada na previsão geral e abstrata de uma norma. Para satisfação das suas necessidades, o homem vale-se de bens. Entre o sujeito e o bem, portanto, forma-se uma relação que, na situação jurídica enfocada, toma o nome de interesse. ${ }^{22}$

${ }^{22}$ FRANÇA, Erasmo Valladão Azevedo e Novaes. Conflito de interesses nas assembleias de S.A. São Paulo: Malheiros, 1993. p. 13-14. 
À luz dos múltiplos interesses presentes, o autor comenta quais seriam as possíveis relações existentes entre os interesses, isto é, relevância, indiferença, possivelmente conflito ou, num viés positivo, solidariedade:

Dada a multiplicidade de interesses que podem competir a um mesmo indivíduo, é de grande utilidade, para o nosso tema, o estudo das relações entre os interesses.

Diz-se, assim, primeiramente, que os interesses podem ter uma relação de relevância ou de indiferença. Há indiferença entre os interesses quando não há qualquer relação ou interferência entre a satisfação de uma necessidade e a de uma outra do mesmo indivíduo. Há relevância quanto existe essa relação ou interferência, que pode ser de solidariedade (ou instrumentalidade) ou de conflito (ou incompatibilidade). ${ }^{23}$

Conflito e solidariedade são duas palavras intrinsicamente relacionadas aos abusos cometidos em sociedades que, naturalmente, remetem ao já comentado dever de lealdade.

A questão do interesse no contexto das sociedades acionárias requer menção ao art. 115 da Lei das S.A. Segundo a norma prevista no caput, caberá ao acionista exercer o seu direito de voto no interesse da companhia. 0 parágrafo $3^{\circ}$ responsabiliza 0 acionista que exerça abusivamente o direito de voto e no parágrafo $4^{\circ}$ positivou-se que deliberação tomada em decorrência de voto de acionista que tenha interesse conflitante com o da companhia é anulável $^{24}$. Percebe-se, assim, a importância conferida pela lei ao interesse da companhia, o que, com efeito, suscita a questão anteriormente proposta quanto à identificação do interesse da companhia em face da multiplicidade de personagens presentes.

O equilíbrio sensível anteriormente mencionado já foi objeto de comentários da doutrina comercialista. Alfredo Lamy Filho assim pontuou:

É mister, por isso, buscar a dificílima linha de conciliação entre o interesse da empresa, cujo êxito deve ser assegurado, do acionista que deve ser protegido contra a fraude, do gestor que precisa de liberdade para agir, do credor que faz jus à segurança de seu crédito e do próprio Estado, fiscal do interesse público em jogo. ${ }^{25}$

\footnotetext{
${ }^{23}$ FRANÇA, Erasmo Valladão Azevedo e Novaes. Conflito de interesses nas assembleias de S.A. São Paulo: Malheiros, 1993. p. 16-17.

${ }^{24} \mathrm{O}$ Código Civil não trata do abuso no exercício do direito de voto de modo tão específico como a Lei das S.A., limitando-se a responsabilizar civilmente por perdas e danos o sócio que, tendo em alguma operação interesse contrário ao da sociedade, participar da deliberação que a aprove graças a seu voto (art. 1.010, $\left.\S 3^{\circ}\right)$.

${ }^{25}$ LAMY FILHO, Alfredo. A Reforma da Lei das Sociedades Anônimas. Revista de Direito Mercantil (RDM), n. 7, 1972, p. 130.
} 
Prosseguindo com o raciocínio apresentado por Alfredo Lamy Filho, a linha de conciliação a ser buscada deve harmonizar os interesses da sociedade, do acionista, do gestor, do credor e do próprio Estado. A pretendida harmonização passa por uma das mais tormentosas discussões existentes entre comercialistas mundo afora, entre os chamados contratualistas e os institucionalistas. Contextualizando a discussão, Erasmo Valladão Azevedo e Novaes França ensina:

0 art. 2.373 do Código Civil Italiano preceitua que o acionista não poderá exercer o direito de voto nas deliberações em que ele tenha, por contra própria ou de terceiro um interesse em conflito com o da sociedade. Da mesma forma, o $\S 1^{\circ}$ do art. 115, da nossa lei das Sociedades por Ações (Lei 6.404, de 15.12.1976), determina que o acionista não poderá votar nas deliberações em que ele tenha interesse conflitante com o da companhia. Em que consiste esse interesse da sociedade ou da companhia, denominado de interesse social (em contraposição ao interesse individual do sócio ou acionista)?

Tendo em vista, sobretudo, a problemática trazida pela grande empresa e suas repercussões sociais, trava-se, desde o início do século, intensa polêmica entre os juristas sobre o conceito de interesse social. Indaga-se, assim, qual o significado de tal expressão: cuida-se, meramente, do interesse coletivo dos sócios? Do interesse da sociedade, como pessoa distinta da dos sócios? Ou também abrange o interesse da empresa, dos trabalhadores, dos credores e da própria comunidade e do país? Tal é a polêmica que monopolizou as atenções dos estudiosos do direito, tendo sido considerada por alguns como o "problema fundamental" das sociedades por ações. E não sem razão, pois não se trata de questão estéril, tendo influenciado ao revés, como se verá, legisladores e juízes na elaboração e aplicação da lei.

As teorias elaboradas em torno do interesse social dividem-se em dois grandes grupos: as teorias institucionalistas e as contratualistas. Para as primeiras, o interesse social abrange também interesses diversos dos interesses dos acionistas $^{26}$; para as segundas, resume-se ele ao interesse coletivo destes. É o critério distintivo fundamental proposta por Jaeger.

Os autores contratualistas enxergam o interesse social exclusivamente como o interesse dos sócios, ao passo que os institucionalistas analisam a questão de maneira mais aberta, defendendo a existência de um interesse superior àquele detido pelos sócios.

Marcelo Vieira von Adamek expõe, detalhadamente, o embate entre as duas principais correntes, explicando que o conceito de interesse social no Código Civil teria um viés mais contratualista, ao passo que a lei acionária brasileira seria de índole institucionalista, demonstrando quão controvertida é a matéria. Enquanto que no regime do Código Civil (art. 1.010) o voto seria exercido como direito subjetivo, na Lei das S.A. o seria como um

\footnotetext{
${ }^{26}$ FRANÇA, Erasmo Valladão Azevedo e Novaes. Conflito de interesses nas assembleias de S.A. São Paulo: Malheiros, 1993. p. 21-22.
} 
direito/função. A partir dessas tormentas, o autor arremata com clareza formulando as seguintes observações críticas:

A primeira observação é a de que, se o interesse social em sentido estrito é definido pelo escopo-meio e pelo escopo-fim - que, genericamente, pode ser chamado de fim comum (fim social) -, a pedra angular do moderno direito societário realmente está, como enfatizam os lúcidos juristas alemães (no subitem 3.3.1, supra), no rico conceito de fim social. Com efeito, se o interesse social é o interesse comum dos sócios na consecução do fim social, o conflito que pode se estabelecer não é propriamente o conflito entre o interesse extrassocial do sócio e o interesse social; é, antes de tudo entre o interesse extrassocial do sócio e o fim comum. A noção de interesse social, que aparece de entremeio, perde a sua necessidade e, portanto, parece mais complicar a solução dos problemas, do que ajudar na sua resolução.

A segunda observação é a de que, rigorosamente, o infindável embate entre contratualistas e institucionalistas talvez não precisasse se colocar em termos de conformação do interesse social e, sim, de qualificação da lei. Por essa trilha, a lei societária é quem teria nuanças institucionalistas, mais ou menos fortes, e não propriamente o interesse social em sentido estrito. Em qualquer caso, o que é possível afirmar, sim, é que a lei societária tem, em alguma medida, natureza institucional, mas o que se nos afigura um equívoco é imaginar que o conceito de interesse social possa gestar em seu interior interesses outros que não o dos sócios.

A terceira observação, por fim, é a de que, no regime do Código Civil, o direito de voto constitui direito subjetivo e, embora lá tenha o legislador tratado do voto conflitante, não se referiu ao voto abusivo, para cuja caracterização tornase necessário recorrer a outros institutos; no regime Lei das S/A, diversamente, o voto é direito/função [...].

Alguns estudiosos, diante do que ficou exposto, colocam em evidência as deficiências práticas da noção de interesse social e outros vão além, e advogam de lege ferenda, o seu abandono e a sua substituição pelos conceitos de fim comum e dever de lealdade. ${ }^{27}$

Pela doutrina citada, verifica-se que o interesse da sociedade, seja ela disciplinada pelo Código Civil ou pela Lei das S.A., deverá ter como norte o dever de lealdade entre os sócios e, no mesmo sentido, o interesse dos sócios uti socii e não uti singuli.

\section{OS ABUSOS DO DIREITO DE SÓCIO EM SOCIEDADES}

Os abusos em sociedades constituem uma disciplina instigante que remete, de pronto, ao exercício do poder de controle. Seja no âmbito de uma sociedade de pessoas, seja de uma grande sociedade de capitais, o apetite por poder, por prestígio e, por que não dizer, vaidade,

\footnotetext{
${ }^{27}$ ADAMEK, Marcelo Vieira von. Abuso de minoria em direito societário. São Paulo: Malheiros, 2014. p. 159-160.
} 
ISSN 1981-3694

(DOI): $10.5902 / 1981369424912$

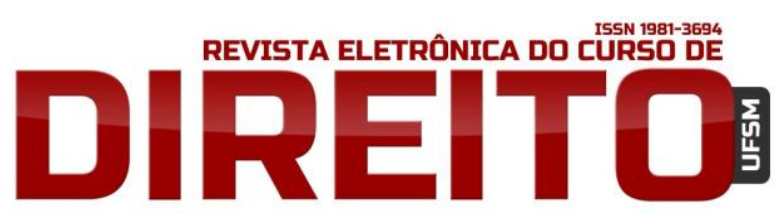

O DEVER DE LEALDADE E OS ABUSOS DO DIREITO DE SÓCIO EM

SOCIEDADES

ALEXANDRE FerReira de ASSUMPÇ̃̃o ALVES ILAN GOLDBERG

determinam que certas decisões sejam tomadas de maneira egoísta, privilegiando interesses particulares em detrimento do interesse da sociedade.

Observando a questão sob o ângulo da minoria e da maioria do capital, o presente texto necessariamente precisaria de maior espaço, o que fugiria ao objetivo inicialmente delineado. Dessa maneira, em virtude dessas limitações, foram analisados alguns casos cujos detalhes tocam nos diversos elementos comentados anteriormente.

Inicialmente, o sentido do verbo abusar, consoante o Dicionário Aurélio, auxilia na compreensão da matéria: “1. Usar ou consumir de forma excessiva, errada ou inconveniente; [...] 3. Insultar; 4. Agir de forma a servir apenas os próprios interesses, mesmo se prejudicando outrem." 28

Os abusos praticados nos contratos de sociedade têm afinidade com a conceituação acima, o que remete, com o propósito de explicar a motivação que está por detrás de tantos conflitos, a uma citação feita por Marcelo Vieira von Adamek no início de sua obra, altamente inspiradora para o presente propósito:

Homens adoram poder [...].

Dê todo o poder à maioria, que ela oprimirá a minoria.

Dê todo o poder à minoria, que ela oprimirá a maioria.

Todos, assim, devem ter poder,

a ser usado por ambos para defender-se, reciprocamente. (tradução livre) ${ }^{29}$

É exatamente como prega o ditado popular: “dê poder ao homem e verás quem ele é”. No interior das mais diversas coletividades, é comum a ideia do convívio entre maiorias e minorias e, logicamente, o ideal é que se dê de forma harmoniosa.

No âmbito do contrato de sociedade, embora sejam mais comuns os abusos praticados pelos sócios titulares de ações ou quotas representativas da maioria do capital, via de regra mais forte, numerosa e poderosa, há também situações nas quais essa lógica se inverte e a minoria, de frequentemente oprimida, passa à condição de opressora, causando inúmeros problemas ao bom funcionamento da sociedade.

É preciso entender, inicialmente, que nessa análise maioria versus minoria o critério quantitativo (número de cabeças) nem sempre será decisivo. Entenda-se bem: uma minoria

\footnotetext{
${ }^{28}$ Disponível em: http://www.dicionariodoaurelio.com/abusar. Acesso em: 13 jul. 2016.

${ }^{29}$ Men love power [...]. Give all power to the many, they will oppress the few. Give all power to the few, they will oppress the many. Both therefore ought to have power, that each may defend itself against the other.

HAMILTON, Alexander apud BOWEN, Catherine Drinker. Miracle at Philadelphia: the Story of the Constitutional Convention May, September 1787. Boston: Back Bay Book, 1986.
} 
ISSN 1981-3694

(DOI): $10.5902 / 1981369424912$

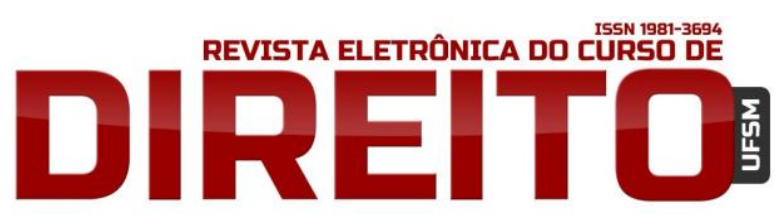

O DEVER DE LEALDADE E OS ABUSOS DO DIREITO DE SÓCIO EM

SOCIEDADES

ALEXANDRE FERREIRA de ASSUMPÇÃo ALVES ILAN GOLDBERG

detentora de parcela considerável do capital social de uma dada sociedade pode, efetivamente, assumir o controle e, assim, dirigi-la. Portanto, aqui se consigna uma importante observação: atentar tanto para o critério quantitativo, quanto para o qualitativo, examinando o contrato/estatuto social, com o propósito de se certificar quanto à regra aplicável ao caso concreto ${ }^{30}$.

Conforme mencionado, a casuística tratando de abusos praticados pela maioria e pela minoria é riquíssima. Para facilitar a compreensão do leitor, a exposição versará, em primeiro lugar, sobre os abusos praticados pela maioria societária para, a seguir, tratar dos abusos praticados pela minoria e, por fim, de certos abusos dos sócios que atinjam o mercado, sob a perspectiva do direito societário vis-à-vis o direito da concorrência (antitruste).

\subsection{Condutas abusivas da maioria}

A primeira casuística refere-se a acionistas majoritários e titulares do poder de controle de certa companhia que deliberaram e aprovaram aumento vultoso do capital social, saltando de um determinado valor para outro quase três vezes maior, com a singela justificava de que a companhia estaria experimentando a expansão dos seus negócios, argumento esse que não fora acompanhado de quaisquer evidências concretas. O referido aumento do capital social implicou apenas na emissão de ações ordinárias, ao passo que a composição das ações da companhia encontrava-se dividida entre ordinárias e preferenciais. É relevante também a questão do preço de emissão das ações que, segundo análise realizada, estaria aquém daquele realmente devido.

A conduta do bloco controlador teve por finalidade enfraquecer e diluir a posição dos minoritários, caracterizando assim o abuso, em prejuízo ao interesse social (o art. 170, § $1^{\circ}$, da Lei $n^{\circ}$ 6.404/76 veda, na fixação do preço de emissão nos aumentos de capital, a diluição

\footnotetext{
${ }^{30}$ Marcelo Vieira von Adamek pontua com propriedade que "Minoria aqui é o não controlador, pouco importando a proporção e a espécie de sua participação societária. 0 termo 'minoria' assume aqui, pois, a ideia de não controlador e constitui, precisamente, uma específica situação jurídica subjetiva de sócio diante da sociedade e dos demais membros. Admite-se, pois, que a minoria (não controladora) possa episodicamente até ser bastante numerosa e detentora de expressiva participação no capital social (mas sem direito de voto) e até se contrapor a um controlador minoritário." (ADAMEK, Marcelo Vieira von. Abuso de minoria em direito societário. São Paulo: Malheiros, 2014. p. 61). No mesmo sentido e de forma ainda mais enfática, Rubens Requião afirma: “Não nos agrada a expressão 'minoria' ou mais particularmente 'proteção da minoria', pois leva a certas ambiguidades e confusões; nem sempre, como se viu, é a maioria de acionistas que controla a sociedade, podendo perfeitamente esse controle ser detido pela minoria, capaz, diante da dispersão e do desinteresse dos acionistas-especuladores e rendeiros, de aglutinar maior número de ações inclusive através de procurações" (REQUIÃO, Rubens. Curso de Direito Comercial. v. 2. 25. ed. São Paulo: Saraiva, 2008. p. 144-145)
} 
ISSN 1981-3694

(DOI): $10.5902 / 1981369424912$

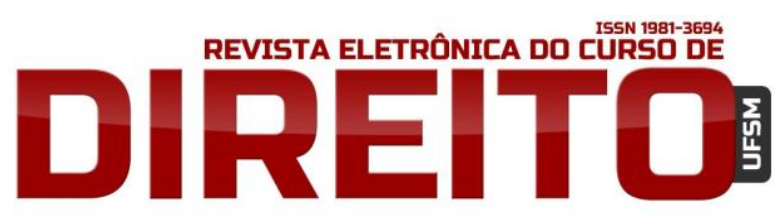

O DEVER DE LEALDADE E OS ABUSOS DO DIREITO DE SÓCIO EM

SOCIEDADES

AleXANDRE FerReira de ASSUMPÇ̃̃o ALVES ILAN GOLDBERG

injustificada da participação dos antigos acionistas). Faz-se oportuno lembrar do dever de lealdade entre todos os sócios e da necessidade de gerir a sociedade no interesse comum uti socii.

Essa hipótese foi objeto de parecer da lavra de Waldírio Bulgarelli que, amparado por sólidos fundamentos, reputou ilegal a conduta adotada pela maioria controladora. De seu arrazoado chamam a atenção os seguintes pontos: (i) aumento do capital social desvirtuado de seu real propósito, isto é, o aumento realizado não geraria reforço ou ampliação do caixa da sociedade, mas, ao contrário, apenas diminuiria sensivelmente a posição dos minoritários; (ii) os abusos praticados pela maioria poderiam ser ilegais, ou, o que seria ainda pior, formalmente legais, porém contrários ao interesse da sociedade. Neste particular, o autor invoca a teoria do "desvio de poder" do direito administrativo; (iii) o aumento do capital social operou-se apenas quanto às ações ordinárias, não havendo proporcionalidade no aumento das ações ordinárias e das preferenciais, com nítidos prejuízos aos sócios minoritários; e (iv) estudos técnicos realizados demonstraram que o aumento do capital social proposto não trouxe ganhos reais à companhia, seja em matéria de liquidez ou rentabilidade (lucratividade) ${ }^{31}$.

\subsection{Condutas abusivas da minoria}

Sob a perspectiva da "tirania dos fracos"32, Waldírio Bulgarelli, em outro parecer, comentou a preocupação eminentemente individualista da minoria do capital, com finalidades obtusas considerando o interesse social. $\mathrm{Na}$ hipótese examinada, a minoria envidou ações para embaraçar a marcha normal dos negócios da sociedade. Entre os fundamentos mencionados pelo parecerista, chamam a atenção: (i) o abuso do direito e (ii) os princípios da confiança e da boafé que, evidentemente, devem nortear o agir de todos os sócios no seio social, independentemente do quantum de participação de cada um ${ }^{33}$.

Retomando a questão sob a perspectiva da minoria que, qualitativamente, assume o

\footnotetext{
${ }^{31}$ BULGARELLI, Waldírio. Sociedades por ações - aumento abuso de capital. Prejuízo dos minoritários e vantagens indevidas dos majoritários. Diluição injustificada da posição dos antigos acionistas. Abuso do poder e conflito de interesses. Anulação da deliberação assembelar que aprovou o aumento e reparação dos danos. Revista dos Tribunais, v. 555, jan. 1982. p. 1039.

32 Expressão utilizada por Marcelo Vieira von Adamek, citando COZIAN, Maurice et al. Droit des sociétés, n. 382. 20. ed. Paris: Litec, 2007. p. 185. (com a nota: "face à la superbe des forts, il faut compter avec la tyrannie des faibles").

33 BULGARELLI, Waldírio. Anulação de assembleia geral de sociedade anônima - assembleias gerais posteriores - abuso de minoria. Revista dos Tribunais, v. 514, ago. 1978. p. 1073.
} 
ISSN 1981-3694

(DOI): $10.5902 / 1981369424912$

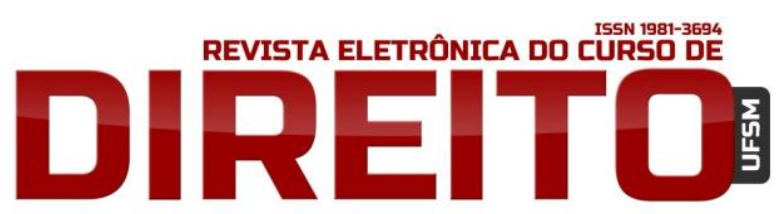

O DEVER DE LEALDADE E OS ABUSOS DO DIREITO DE SÓCIO EM

SOCIEDADES

ALEXANDRE FerReIRA de ASSUMPÇÃo ALVES ILAN GOLDBERG

controle da sociedade, o conflito entre os interesses do controlador - uti singuli e os interesses dos demais sócios (da própria sociedade - uti socii) foi apreciado pelo Tribunal de Justiça do Estado de São Paulo ${ }^{34}$, só que num contexto além da discussão societária. No caso concreto, travou-se um litígio entre Procid Participações e Negócios S.A. e o Banco Santos S.A., no polo ativo, contra Unibanco AIG Seguros e IRB Brasil Resseguros S.A., no polo passivo, motivado pela contratação de seguro de responsabilidade civil para diretores e administradores, o conhecido seguro D\&O (Directors \& Officers). Tendo como objetivo a transferência do risco que incide sobre o patrimônio pessoal dos administradores/diretores, este seguro visa, prima facie, a protegê-los, desde que, naturalmente, sua conduta seja regular.

O Banco Santos S.A., consoante noticiado pela mídia à época, acabou sendo liquidado (regime de liquidação extrajudicial realizado pelo Banco Central), oportunidade na qual demandas diversas foram ajuizadas contra a pessoa jurídica e seu acionista controlador.

No âmbito das investigações realizadas, apurou-se a ocorrência de nítido conflito de interesses entre o acionista controlador e os interesses da sociedade, exatamente como explicado anteriormente. O conflito deu-se na exata medida em que o acionista controlador, privilegiando seus próprios e exclusivos interesses, acabou transferindo para seu patrimônio pessoal parte considerável dos ativos da companhia, deixando-a em situação financeira difícil. Assim, considerando a intencionalidade da conduta, a seguradora acabou negando a cobertura pretendida pelo segurado, o que acabou ensejando a prolação do acórdão anteriormente mencionado pelo Tribunal de Justiça do Estado de São Paulo.

0 percuciente voto do relator foi denso, pesquisando em doutrina estrangeira a fundamentação que o acabou convencendo a prestigiar a negativa praticada pela seguradora, calcado em diversos fundamentos, dentre os quais convém destacar: (i) a omissão de informações relevantes no momento pretérito à contratação do seguro e (ii) a não aplicabilidade da business judgment rule ante o conflito de interesses entre o controlador e a sociedade. A conduta intencional, no caso concreto do contrato de seguro, gera a sua nulidade e perda do direito à garantia (art. 762 do Código Civil).

Concluindo o presente tópico, Erasmo Valladão de Azevedo e França, quanto à conduta

\footnotetext{
${ }^{34}$ SÃO PAULO. Tribunal de Justiça do Estado de São Paulo. Apelação Cível 543.194-4/9-00. Apelantes: Procid Participações e Negócios S.A. e Banco Santos S.A. Apelados: Unibanco Aig Seguros e Previdência e IRB Brasil Resseguros S.A. Relator: Desembargador Vito Guglielmi. 11 de dezembro de 2008. Disponível em:

https: / /esaj.tjsp.jus.br/cjsg/getArquivo.do?conversationld=\&cdAcordao=3396747\&cdForo=0\&uuidCaptcha =sajcaptcha_aedfb9aaaebe47d6bf58389314f499d1\&vlCaptcha=ffi\&novoVlCaptcha=. Acesso em: 19 jul. 2017.
} 
do controlador, afirma: “Ora, embora seja controlador, ele não deixa de ser acionista, não podendo portanto pretender, nessa qualidade, vantagens diversas das que competem, por lei, aos demais acionistas." 35 Uma vez mais, o dever societário de lealdade está presente como fundamento, seja para o administrador ou para o controlador como se infere da leitura do art. 116, parágrafo único, da Lei $\mathrm{n}^{\circ}$ 6.404/76: “O acionista controlador [...] tem deveres e responsabilidades para com os demais acionistas da empresa, os que nela trabalham e para com a comunidade em que atua, cujos direitos e interesses deve lealmente respeitar e atender" ${ }^{36}$.

\subsection{Direito concorrencial - o mercado como vítima}

Ao demonstrar preocupação com o bom funcionamento do mercado, Fábio Ulhôa Coelho afirma que "diferentes objetivos reclamam diferentes padrões normativos" ${ }^{\text {37 }}$. Na perspectiva do direito societário, o objetivo encontra-se voltado à proteção dos acionistas minoritários; já na perspectiva do direito concorrencial o objetivo alude ao bom funcionamento do mercado, no sentido de evitar práticas anticoncorrenciais (art. 173, § $4^{\circ}$, da Constituição), abuso de posição dominante e, assim, lesão aos interesses dos consumidores. Essa é a finalidade da Lei $n^{\circ}$ 12.529/2001, que dispõe sobre a prevenção e a repressão às infrações contra a ordem econômica, orientada pelos ditames constitucionais de liberdade de iniciativa, livre concorrência, função social da propriedade, defesa dos consumidores e repressão ao abuso do poder econômico.

Emerge a necessidade de conjugar dispositivos de ordem societária e de ordem concorrencial, alcançando o objetivo colimado e expressamente previsto no art. 170, IV, da Constituição Federal, isto é, a livre concorrência. A respeito, pronunciou-se Fábio Ulhôa Coelho:

Se as normas legais e infra-legais destinadas, direta ou indiretamente, a impedir ou reprimir práticas anticoncorrenciais ficarem adstritas ao conceito de controlador do direito das sociedades (construído para atender à devida composição dos interesses intrasocietários), podem acabar não cumprindo, satisfatoriamente, o determinado no texto constitucional, ao deixarem de

\footnotetext{
${ }^{35}$ FRANÇA, Erasmo Valladão Azevedo e Novaes. Op. Cit., p. 85-86.

${ }^{36}$ BRASIL. Lei $n^{\circ} 6.404$, de 15 de dezembro de 1976. Dispõe sobre as Sociedades por Ações. Diário Oficial da República Federativa do Brasil, Brasília, DF, 17 dez. 1976. Disponível em: http://www.planalto.gov.br/ccivil_03/leis/L6404consol.htm. Acesso em: 19 jul. 2017.

${ }^{37}$ COELHO, Fábio Ulhôa. O conceito de poder de controle na disciplina jurídica da concorrência. Revista do Instituto dos Advogados de São Paulo, v. 3, jan./jun. 1999. p. 22.
} 
reprimir certas modalidades de infração da ordem econômica. ${ }^{38}$

No mesmo sentido, Calixto Salomão Filho pondera que os objetivos do direito societário e do direito concorrencial são diferentes, de maneira que o atingimento dos objetivos de ambos requer condutas distintas:

[...] objeto de proteção do direito societário são, em primeira linha, os interesses dos acionistas minoritários e dos credores, enquanto as preocupações do direito concorrencial se centram, como já visto, em concorrentes e consumidores. Ocorre que os interesses desses diferentes grupos nem sempre, aliás raramente, coincidem. Práticas que configuram abuso de posição dominante, claramente prejudiciais aos consumidores, são benéficas a minoritários e credores, na medida em que produzem lucros extraordinários. Essa diferença de objetivos e de interesses protegidos sugere a necessidade de fixar as diferenças entre empresas e os conceitos societários correspondentes. ${ }^{39}$

Com efeito, as questões relativas aos eventuais abusos praticados em sociedades, numa primeira abordagem, realmente tocam no relacionamento entre os acionistas, deflagrando diversos conflitos entre minoritários e majoritários. A partir dos elementos acima colhidos verifica-se que as repercussões dos atos abusivos não ficam limitadas à própria sociedade, pois poderão ser sensivelmente prejudiciais ao mercado, aos consumidores e à própria comunidade. Nessa linha de raciocínio, afigura-se de todo pertinente que o controle quanto aos abusos seja realizado tanto do ponto de vista societário, quanto do ponto de vista concorrencial, zelando, assim, pelos interesses dos acionistas, dos credores, dos consumidores, ou seja, do mercado como um todo.

\section{CONCLUSÃO}

A investigação dos abusos por parte de sócios em sociedades está relacionada à função social do contrato e, ato contínuo, à função social da sociedade.

O valor social da livre iniciativa, um dos fundamentos republicanos insculpidos na Constituição e que se irradia na interpretação e aplicação das normas de todo ordenamento jurídico, impõe às sociedades - através da atuação dos sócios controladores e administradores atentar para os interesses de terceiros, além da distribuição de lucros entre os seus sócios. Somente assim haverá convivência harmônica no seio da sociedade e tutela de todos os

${ }^{38}$ COELHO, Fábio Ulhôa. O conceito de poder de controle na disciplina jurídica da concorrência. Revista do Instituto dos Advogados de São Paulo, v. 3, jan./jun. 1999. p. 3.

${ }^{39}$ SALOMÃO FILHO, Calixto. Direito concorrencial: as estruturas. São Paulo: Malheiros, 1998. p. 241. 
interesses, isto é, dos sócios, empregados, consumidores, meio ambiente e, também, do mercado como um todo, realizando-se objetivos e princípios da Ordem Econômica (v.g. valorização do trabalho humano, existência digna, busca pelo pleno emprego, livre concorrência, função social da propriedade).

A questão intrassocial tem como eixo principal o dever societário de lealdade que, também como explicado, originou-se da cláusula geral de boa-fé objetiva, positivada no Código Civil pelo artigo 422.

Dessa maneira, quaisquer condutas que sejam tomadas pelos sócios, seja na condição de representantes da maioria, seja da minoria, deverão estar pautadas no dever societário de lealdade e, sempre que inobservado esse postulado, caracterizada estará a conduta abusiva e suas consequentes repercussões.

Em síntese, a vida em sociedade requer a observância por todos os sócios do interesse comum, que é o interesse da sociedade (uti socii) e não os interesses individuais dos sócios (uti singuli). Quando houver conflito de interesses entre o interesse individual e o interesse da sociedade, prevalecerá este.

\section{REFERÊNCIAS}

ADAMEK, Marcelo Vieira von. Abuso de minoria em direito societário. São Paulo: Malheiros, 2014.

AGUIAR, Danilo Augusto Barboza de. Proteção dos acionistas minoritários nas sociedades anônimas abertas como forma de promover o desenvolvimento do mercado de capitais nacional. Alterações no regime legal das ações preferenciais. In: Revista de Direito Bancário e do Mercado de Capitais, v. 22, p. 88-127, out./dez. 2003.

BERTOLDI, Marcelo M.; RIBEIRO, Marcia Carla P. Curso avançado de direito comercial. 5. ed. São Paulo: RT, 2009.

BETTI, Emilio. Teoria geral do negócio jurídico. Tomo I. Tradução de Ricardo Rodrigues Gama. Campinas: LZN, 2003.

BRASIL. Lei $\mathrm{n}^{\circ}$ 6.404, de 15 de dezembro de 1976. Dispõe sobre as Sociedades por Ações. Diário Oficial da República Federativa do Brasil, Brasília, DF, 17 dez. 1976. Disponível em:

<http://www.planalto.gov.br/ccivil_03/leis/L6404consol.htm> Acesso em: 19 jul. 2017.

BRASIL. Lei ${ }^{\circ} 10.406$, de 10 de janeiro de 2002. Código Civil. Diário Oficial da República

Federativa do Brasil, Brasília, DF, 11 jan. 2002. Disponível em:

http://www.planalto.gov.br/ccivil_03/leis/2002/L10406.htm. Acesso em: 18 jul. 2017. 
ISSN 1981-3694

(DOI): $10.5902 / 1981369424912$

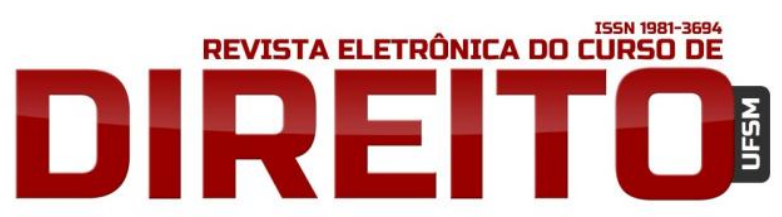

O DEVER DE LEALDADE E OS ABUSOS DO DIREITO DE SÓCIO EM

SOCIEDADES

ALEXANDRE FERREIRA DE ASSUMPÇÃo ALVES ILAN GOLDBERG

BRASIL. Superior Tribunal de Justiça. Recurso Especial $n^{\circ} 1192726 / S C$. Francisco Francovig e outros; Santa Terezinha Transportes e Turismo Ltda. Relator: Min. Ricardo Villas Bôas Cueva. 20 de março de 2015. Disponível em:

https://ww2.stj.jus.br/processo/revista/documento/mediado/?componente=ITA\&sequencial=13 90551\&num_registro=201000836598\&data=20150320\&formato=PDF. Acesso em: 19 jul. 2017.

BRASIL. Superior Tribunal de Justiça. Recurso Especial 1179342/GO. Cilene Maria Elias Metran e Goiás Refrigerantes S/A. Relator: Min. Luis Felipe Salomão. 01 de agosto de 2014. Disponível em: https://ww2.stj.jus.br/processo/revista/documento/mediado/?componente=ITA\&sequencial=13 25480\&num_registro=201000260074\&data=20140801\&formato=PDF. Acesso em: 19 jul. 2017.

BULGARELLI, Waldírio. Anulação de assembleia geral de sociedade anônima - assembleias gerais posteriores - abuso de minoria. Revista dos Tribunais, v. 514, p. 1067-1079, ago. 1978.

BULGARELLI, Waldírio. Sociedades por ações - aumento abuso de capital. Prejuízo dos minoritários e vantagens indevidas dos majoritários. Diluição injustificada da posição dos antigos acionistas. Abuso do poder e conflito de interesses. Anulação da deliberação assembelar que aprovou o aumento e reparação dos danos. Revista dos Tribunais, v. 555, p. 1029-1050, jan. 1982.

COELHO, Fábio Ulhôa. O conceito de poder de controle na disciplina jurídica da concorrência. Revista do Instituto dos Advogados de São Paulo, v. 3, p. 19-25, jan./jun. 1999.

COMPARATO, Fábio Konder. Estado, empresa e função social. Revista dos Tribunais, São Paulo, v. 85, n. 732, p. 38-46, out. 1996.

COZIAN, Maurice et al. Droit des sociétés, n. 382. 20. ed. Paris: Litec, 2007.

DUGUIT, Léon. Las transformaciones del Derecho Publico y Privado. Buenos Aires: Heliasta S.R.L., 1975.

FRANÇA, Erasmo Valladão Azevedo e Novaes. Conflito de interesses nas assembleias de S.A. São Paulo: Malheiros, 1993.

GAMA, Guilherme Calmon Nogueira da; BARTHOLO, Bruno Paiva. Função social da empresa. In: Revista dos Tribunais, v. 96, n. 857, p. 11-28, mar. 2007.

HAMILTON, Alexander apud BOWEN, Catherine Drinker. Miracle at Philadelphia: the Story of the Constitutional Convention May, September 1787. Boston: Back Bay Book, 1986.

LAMY FILHO, Alfredo. A Reforma da Lei das Sociedades Anônimas. Revista de Direito Mercantil (RDM), n. 7, p. 123-158, 1972.

REALE, Miguel. Novo código civil: exposição de motivos e texto sancionado. 2. ed. Brasília: Senado Federal, Subsecretaria de Edições Técnicas, 2005. Disponível em: http://www2.senado.leg.br/bdsf/item/id/70319. Acesso em: 12 ago. 2016. 
RENNER, Karl. The Institutions of Private Law and their Social Functions. New Brunswick (U.S.): Transaction Publishers, 2010.

REQUIÃO, Rubens. Curso de Direito Comercial. v. 2. 25. ed. São Paulo: Saraiva, 2008.

ROPPO, Enzo. O contrato. Tradução de Ana Coimbra e M. Januário C. Gomes. Coimbra: Almedina, 2009.

SALOMÃO FILHO, Calixto. Direito concorrencial: as estruturas. São Paulo: Malheiros, 1998.

SÃO PAULO. Tribunal de Justiça do Estado de São Paulo. Apelação Cível 543.194-4/9-00. Apelantes: Procid Participações e Negócios S.A. e Banco Santos S.A. Apelados: Unibanco Aig Seguros e Previdência e IRB Brasil Resseguros S.A. Relator: Desembargador Vito Guglielmi. 11 de dezembro de 2008. Disponível em:

https: / /esaj.tjsp.jus.br/cjsg/getArquivo.do?conversationld=\&cdAcordao=3396747\&cdForo=0\&uui dCaptcha=sajcaptcha_aedfb9aaaebe47d6bf58389314f499d1\&vlCaptcha=ffi\&novoVICaptcha $=$. Acesso em: 19 jul. 2017.

SILVA, Alexandre Couto. Responsabilidade Civil dos Administradores de S/A: business judgment rule. Rio de Janeiro: Elsevier, 2007.

WALD, Arnoldo. 0 governo das empresas. Revista de Direito Bancário e do Mercado de Capitais, v. 5, n. 15, p. 53-78, jan./mar. 2002.

WARDE JÚNIOR, Walfrido Jorge; CASTRO, Rodrigo Rocha Monteiro de. Poderes de controle no âmbito da companhia. In: CASTRO, Rodrigo Rocha Monteiro (Coord.). Direito Empresarial e outros estudos em homenagem ao Professor José Alexandre Tavares Guerreiro. São Paulo: Quartier Latin, 2013. p. 495-513.

Recebido em: 27/11/2016 / Revisões requeridas em: 24/05/2017 / Aprovado em: 31/05/2017

\section{COMO CITAR O ARTIGO (ABNT)}

ALVES, Alexandre Ferreira de Assumpção; GOLDBERG, Ilan. O DEVER DE LEALDADE E OS ABUSOS DO DIREITO DE SÓCIO EM SOCIEDADES. Revista Eletrônica do Curso de Direito da UFSM, Santa Maria, RS, v. 12, n. 2, p. 472-496, ago. 2017. ISSN 19813694. Disponível em: <https://periodicos.ufsm.br/revistadireito/article/view/24912>. Acesso em: dia mês. ano. doi:http://dx.doi.org/10.5902/1981369424912. 